\title{
ARTICLES
}

\section{LEGAL EDUCATION IN THE BRICS COUNTRIES IN THE CONTEXT OF GLOBALIZATION: A COMPARATIVE ANALYSIS}

\author{
OLEG VINNICHENKO, \\ Tyumen State University (Tyumen, Russia) \\ ELENA GLADUN, \\ Tyumen State University (Tyumen, Russia)
}

DOI: $10.21684 / 2412-2343-2018-5-3-4-39$

Legal education in the contemporary world is changing. The main influences are linked to developments in transportation and communication and the enmeshing of diverse economies embraced by globalization. Law schools confront more mobile and more ambitious students who wish to experience different jurisdictional practices, to serve the increasingly global business community and to be more competitive. This research examines the modifications required in legal education as a result of globalization with specific reference to law schools in the BRICS countries of Brazil, Russia, India and China.

Research on higher education, and legal education in particular, has been growing in recent years, yet there is still a gap in the study and comparison of the specifics of legal education within the BRICS countries. This research makes an attempt to analyze and contrast the current goals, objectives, structure and quality of higher legal education in Brazil, Russia, India and China. The specifics of law schools have been studied over the past twenty years in correlation with economic, cultural and education trends in BRICS and globally.

Based on research literature, practitioner literature and legislative sources, this paper outlines common and special features of lawyer training in BRICS. The prime similarity of the legal education systems in BRICS are global education trends and the influence of the U.S. and UK education systems. Each BRICS country experienced an "explosion" in the popularity of legal education and, consequently, the urgent need to reform the education 
process in order to attain better quality and affordability. The result of these reforms, taking place in each country from 1950 to today, has become the growing differentiator of the educational institutions, turning them into "elite" and "mass" law schools.

The facets of legal education in Brazil, Russia, India and China are attributed to their national policies as well as the historical development of the educational institutions and their perception of what specific lawyer skills and competencies are demanded by the legal market and national population. We conclude that the structure and quality of legal education as well as the requirements and monitoring tools vary in each country. These are dependent on several factors: the specific country's ideology, its economic development, its proximity to an "Eastern" or "Western" model, its ability to learn from foreign education systems and its attempts at self-identification in the global educational space.

Keywords: legal education; goals and quality; structure of legal education; the BRICS countries.

Recommended citation: Oleg Vinnichenko \& Elena Gladun, Legal Education in the BRICS Countries in the Context of Globalization: A Comparative Analysis, 5(3) BRICS Law Journal 4-39 (2018).

\section{Table of Contents}

\section{Introduction}

1. Goals and Objectives of Higher Legal Education in Brazil, Russia, India and China

2. Structure of Legal Education at the Universities of Brazil, India, China and Russia

2.1. Brazil

2.2. India

2.3. China

2.4. Russia

3. Conclusions on the Structure of Legal Education

4. Quality of Legal Education in India, Brazil, China and Russia 4.1. India

4.2. Brazil

4.3. China and Russia

5. Conclusions on the Quality of Legal Education

Conclusion - Tendencies and Challenges of Legal Education in the BRICS Countries 


\section{Introduction}

In an ever-increasingly globalized world, the role of the BRICS countries (Brazil, Russia, India, China and South Africa) is significantly and rapidly changing.' Originally, BRIC was introduced in 2006 (in 2010 South Africa was invited to join the group, which then became known as BRICS) as an economic and financial structure comprising the growing economies that potentially were capable of providing for a multipolar world and the global economy, and playing a leading role in global governance. Over the past few decades the BRICS countries have played a vital role in globalization. BRICS economic growth and social inclusion policies have helped stabilize the global economy, foster job creation, reduce poverty and combat inequality. ${ }^{2}$ In particular, strong GDP growth has seen BRICS become engines of the global economy. ${ }^{3}$

In 2017, the gross domestic product (GDP) - taking into account purchasing power parity (PPP) - of BRICS was ranked in the top quartile of countries worldwide: China was first in this ranking, India fourth, Russia seventh, Brazil ninth and South Africa thirty-first. ${ }^{4}$ Quantitative indicators confirm the BRICS members' high ranking in terms of human resources (population) and the size of their geographic territories (see Table 1).

Table 1: BRICS Countries Indicators

\begin{tabular}{|c|c|c|c|c|c|}
\hline & China & India & Brazil & Russia & $\begin{array}{c}\text { South } \\
\text { Africa }\end{array}$ \\
\hline $\begin{array}{c}\text { Population } \\
\text { (mln. people) }\end{array}$ & $1,378.6$ & $1,324.2$ & 207.7 & 144.3 & 55.9 \\
\hline $\begin{array}{c}\text { Territory } \\
\text { (mln. square km.) }\end{array}$ & 9.6 & 3.3 & 8.5 & 17.1 & 1.2 \\
\hline $\begin{array}{c}\text { GDP } \\
\text { (bln. U.S. dollars) }\end{array}$ & $11,199.1$ & $2,263.5$ & $1,796.2$ & $1,283.2$ & 294.8 \\
\hline
\end{tabular}

Pedro Morazán et al., The Role of BRICS in the Developing World, Directorate-General for External Policies of the European Union (2012) (Sep. 10, 2018), available at https://www.ab.gov.tr/files/ardb/evt/1_avrupa_ birligi/1_9_politikalar/1_9_8_dis_politika/The_role_of_BRICS_in_the_developing_world.pdf.

2 Towards a Long-Term Strategy for BRICS: A Proposal by the BRICS Think Tanks Council (2015) (Sep. 10, 2018), available at http://www.nkibrics.ru/ckeditor_assets/attachments/55cca92662726921aa02000 0/na_puti_k_dolgosrochnoy_strategii_stran_briks_angl.pdf?1439476006.

3 Irina G. Radulescua et al., BRICS Countries Challenge to the World Economy New Trends, 8 Procedia Economics and Finance 605, 605-613 (2014).

4 Central Intelligence Agency, The World Factbook (2017) (Sep. 10, 2018), available at https://www.cia. gov/library/publications/resources/the-world-factbook/rankorder/2001rank.html.

5 БРИКС в цифрах и фактах // РИА Новости. 2 сентября 2017 г. [BRICS in Dates and Facts, RIA News, 2 September 2017] (Sep. 10, 2018), available at https://ria.ru/infografika/20170902/1501572657.html. 
Russia and Brazil's economies share similarities in terms of vast natural resources as well as well-developed agricultural and mining sectors. For a large part, both countries' economic growth relies on the volume of trade in raw materials and natural resources. India has developed competitive industries in pharmaceutical production and IT technologies, and its service sector contributes around 48.93 percent of GDP. ${ }^{6}$ China is the world leader in terms of production volume and is referred to as the "world factory" of consumer products. ${ }^{8}$ According to the World Bank, the economic growth rates of Brazil and Russia have declined over the past four years, while the Chinese economy is experiencing further rapid growth (see Chart 1). The crisis in Brazil and Russia is associated with a fall in world energy prices as well as international economic sanctions imposed on Russia by several Western countries.'

Chart 1: GDP by PPP, prices in 2011, billion U.S. dollars

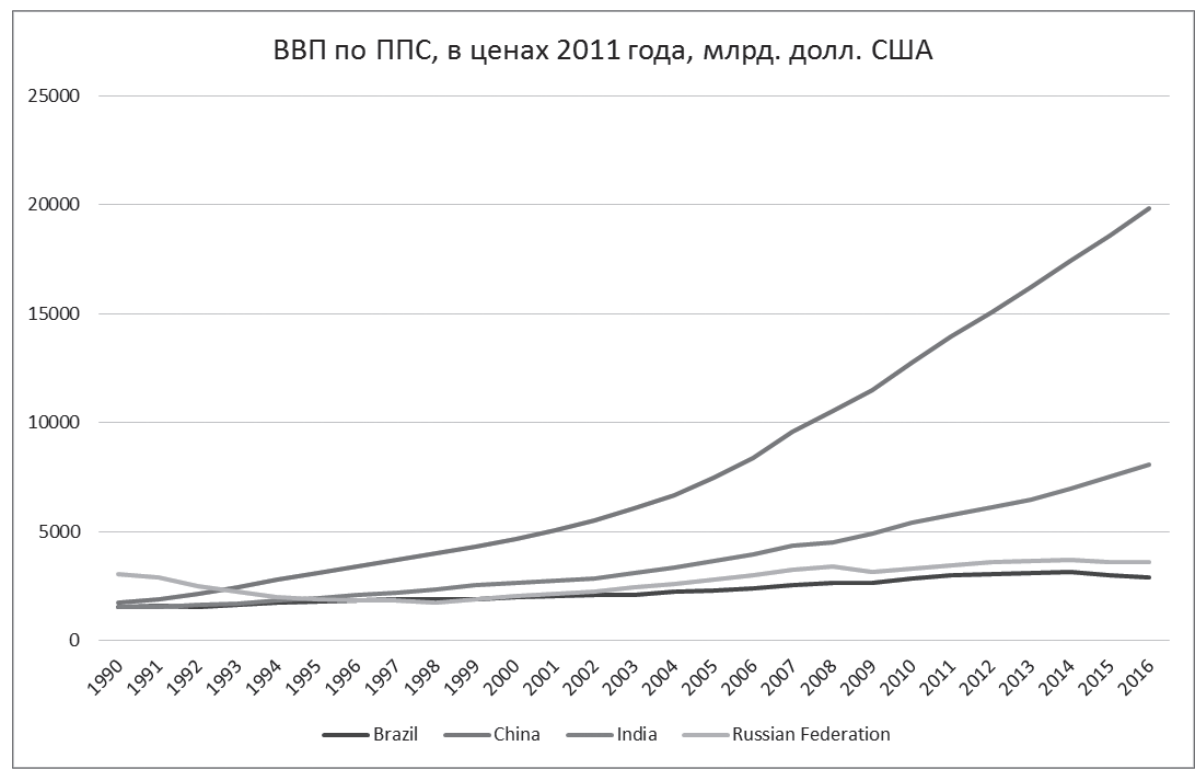

6 India: Distribution of Gross Domestic Product (GDP) Across Economic Sectors from 2007 to 2017, Statista (2017) (Sep. 10, 2018), available at https://www.statista.com/statistics/271329/distributionof-gross-domestic-product-gdp-across-economic-sectors-in-india.

7 Yih-chyi Chuang \& Simona Thomas, China and the World Economy: China's Economic Rise After Three Decades of Reform 17 (Berlin: LIT, 2010).

8 Phillip Inman, China Overtakes US in World Trade, The Guardian, 11 February 2013 (Sep. 10, 2018), available at https://www.theguardian.com/business/2013/feb/11/china-worlds-largest-trading-nation.

9 Featured Indicators, The World Bank (2018) (Sep. 10, 2018), available at https://data.worldbank.org/ indicator/?tab=featured. 
Furthermore, BRICS continue to play an important role on the global stage due to the following shared factors: ${ }^{10}$

- they are developing countries with growing global economic performance and high potential;

- they are countries with systemic importance in the world economy; in this respect their national performances have had profound implications, both regionally and globally;

- they are able to exert influence on global governance.

Economic processes and education are intertwined. Numerous articles discuss and confirm the connection between higher education rates of enrollment and a country's economic growth." On the one hand, a country's economy has a strong impact on culture, education and other social sectors, where increased public and private investment in human capital stimulate a higher level of education in the nation, while, on the other hand, education affects economic growth. For an economy, education can increase labor productivity and thus can lead to a higher level of output. ${ }^{12}$ It can also increase the innovative capacity of the economy improving knowledge of new technologies, products and processes promotes growth. ${ }^{13}$

Economic processes are becoming ever more important drivers for changes in the global market of legal services. International and corporate law and practice have experienced demand for new legal skills and competencies. In these circumstances, a new perception of what a successful lawyer is has been formed, implying that not only a basic legal education and knowledge of the national legal system is required but also the capacity to address international private (economic) law, to understand business and to be able to navigate across global legal issues and processes which are equally important. Worldwide, there has been significant expansion in both the amount of knowledge and the number of new specialized fields with which lawyers have to deal. There has been a rapid expansion in the international regulation of trade and financial

10 Edwin M. Truman, Implications of Structural Changes in the Global Economy for Its Management, Paper delivered at the World Economic Forum-Reinventing Bretton Woods Committee Roundtable on Global Savings and Investments Patterns and the Changing Structure of the World Economy Adelaide, Australia, 18 March 2006 (Sep. 10, 2018), available at https://piie.com/publications/papers/ truman0306.pdf.

11 OECD, Higher Education at a Glance (2017) (Sep. 10, 2018), available at http://www.oecd.org/ education/education-at-a-glance-19991487.htm; Bas Jacobs \& Frederick van der Ploeg, Guide to Reform of Higher Education: A European Perspective, 21(47) Economic Policy 535, 535-592 (2006).

12 N. Gregory Mankiw et al., A Contribution to the Empirics of Economic Growth, 107(2) Quarterly Journal of Economics 407, 437 (1992).

13 Robert E. Lucas, Jr., On the Mechanics of Economic Development, 22(1) Journal of Monetary Economics 3, 3-42 (1988); Philippe Aghion \& Peter Howitt, Endogenous Growth Theory (Cambridge: MIT Press, 1998); Paul Romer, Endogenous Technological Change, 98(5) Journal of Political Economy S71, S71S102 (1990). 
transactions in areas such as payment systems, natural resource contracts, licensing, franchising, intellectual property, establishing and managing foreign investment, and the resolution of international disputes, to name a few areas. ${ }^{14}$

Legal professions in the BRICS group face global challenges as well as challenges associated with their national legal systems. They are asked to provide relevant solutions in accordance with new circumstances and legal relationships (i.e. business development, higher quality of legal services; changes in the social structure of a population; development of the digital economy and internet technologies; changes in political life, etc.). Moreover, legal education is experiencing profound changes around the world due to new global education trends..$^{15}$

The World Declaration on Higher Education for the Twenty-First Century: Vision and Action, in its Preamble states:

Without adequate higher education and research institutions providing a critical mass of skilled and educated people, no country can ensure genuine endogenous and sustainable development and, in particular, developing countries and least developed countries cannot reduce the gap separating them from the industrially developed ones. Sharing knowledge, international co-operation and new technologies can offer new opportunities to reduce this gap. ${ }^{16}$

The educational level of a nation can be a crucial factor that contributes to the economic growth of BRICS. Furthermore, education enhances the quality of human capital and, additionally, human capital contributes to economic development. ${ }^{17}$

Over the past few decades, countries such as Russia have faced a crisis in legal education. Law schools in universities around the world face changes due to active reforms and changes in traditions and settled techniques. Previous approaches no longer meet existing requirements, thus it is necessary to explore a new role for

14 Ralph H. Folsom et al., International Business Transactions: A Problem-Oriented Coursebook $\left(11^{\text {th }}\right.$ ed., St. Paul, MN: West, 2012); Mathias W. Reimann et al., Transnational Law: Cases and Materials (St. Paul, MN: West, 2013).

15 John Flood, Legal Education in the Global Context: Challenges from Globalization, Technology and Changes in Government Regulation, Report for the Legal Services Board (2007) (Sep. 10, 2018), available at https://www.legalservicesboard.org.uk/news_publications/latest_news/pdf/lsb_legal_education_ report_flood.pdf. See also Peter Smith, The Legal Education - Legal Practice Relationship: A Critical Evaluation, Sheffield Hallam University, Master's Thesis (2015) (Sep. 10, 2018), available at http:// shura.shu.ac.uk/information.html.

16 UNESCO, World Declaration on Higher Education for the Twenty-First Century: Vision and Action, 9 October 1998 (Sep. 10, 2018), available at http://www.unesco.org/education/educprog/wche/ declaration_eng.htm.

17 Yuah Sheng-jun, Educational Policies and Economic Growth in BRICS: Comparative Perspectives, 8(2) Journal of US-China Public Administration 188, 188-197 (2011). 
legal education in a changing world..$^{18}$ One of the main factors affecting the goals and quality of legal education in Russia is the complicated relationship between the Russian Federation and European countries, specifically the partial withdrawal of the Russian Federation from the European legal space. Russia's withdrawal from the European Convention on Human Rights is an issue for heated discussion based on a Supreme Court decision. ${ }^{19}$ Russia is now considering completely withdrawing from the Convention and ending cooperation with the European Court of Human Rights and the Council of Europe..$^{20}$ If such steps are taken, they will inevitably alter the content and performance of the legal profession and, consequently, the legal education process.

Taking into account the background across which the legal education reforms in BRICS are taking place, this paper attempts to analyze and compare the goals, quality and structure of legal education in the BRICS countries with a focus on their specific characteristics, dynamics and economic background. The purpose and particularity of higher legal education in these countries are largely determined by the distinct features of their economic and political agendas. We address four BRICS countries (Brazil, Russia, India, China) due to limited information being available about the legal education system in South Africa, which, as mentioned earlier, entered the group later than the other members and is not highly ranked in terms of GDP.

In the context of the globalization of the legal profession, empirical research on training and education is especially important. A number of books and research papers discuss different issues related to legal education in BRICS. The volume of publications can be divided into two blocks: (1) general descriptions of the higher legal education system in the BRICS countries in the context of globalization; ${ }^{21}$ (2) aspects of legal education in BRICS (i.e. public policy in the field of legal education, reforms of legal education, quality of education, theory and practice of future

18 Dmitry Maleshin, The Crisis of Russian Legal Education in Comparative Prospect, 66(2) Journal of Legal Education 289, 290 (2017).

19 Постановление Конституционного Суда Российской Федерации от 14 июля 2015 г. № 21-П [Ruling of the Constitutional Court of the Russian Federation No. 21-P of 14 July 2015] (Sep. 10, 2018), available at https://rg.ru/2015/07/27/ks-dok.html; Постановление Конституционного Суда Российской Федерации от 19 января 2017 г. № 1-П, Собрание законодательства РФ, 2017, № 5, ст. 866 [Ruling of the Constitutional Court of the Russian Federation No. 1-P of 19 January 2017, Legislation Bulletin of the Russian Federation, 2017, No. 5, Art. 866].

20 Russia May End Cooperation with European Court of Human Rights: RIA, Reuters, 1 March 2018 (Sep. 10, 2018), available at https://www.reuters.com/article/us-russia-court-echr-withdrawal/russia-may-endcooperation-with-european-court-of-human-rights-ria-idUSKCN1GD47U.

21 Flood, supra note 15. See also Sheng-jun 2011; The Brazilian Legal Profession in the Age of Globalization: The Rise of the Corporate Legal Sector and Its Impact on Lawyers and Society (L. Gross Cunha et al. (eds.), Cambridge: Cambridge University Press, 2017); Amit K. Kashyap, Professional Legal Education in India: Challenges and the Way Forward, 7(3) Educational Quest: An International Journal of Education and Applied Social Sciences 141, 141-147 (2016); Legal Education in India: Issues and Challenges (K.L. Gupta (ed.), Germany: Lambert Academic Publication, 2017). 
lawyer training). ${ }^{22}$ Despite a plethora of research devoted to legal education in BRICS, a comprehensive comparative analysis of its structure and content has not been carried out to date. Therefore, the objective of our paper is to analyze the characteristics, objectives, quality and system of legal education in four countries of the BRICS group.

\section{Goals and Objectives of Higher Legal Education in Brazil, Russia, India and China}

Legal education is a broad concept. It includes training professionals for practicing in courts, law teaching, law research, administration in different areas, legal consulting in commercial and industrial companies and other activities which postulate and require legal knowledge and skills. Legal education stands for the enrichment of human sensibility, and it not only develops lawyers but also creates cultured lawabiding citizens who are aware of human values, legal ethics and human rights. ${ }^{23}$

The core objective of legal education in universities is to enable students to get the essential legal competencies and skills, formalizing this process by gaining official certification. It is a necessary requirement for admission to certain types of legal practice (i.e. an advocate or judge).

This objective seems to be rather dynamic. Social changes, market demands and other drivers force the legal education system to adapt over time. To date, legal education is contrasted to social studies because most law school graduates build their careers in other spheres (e.g. as managers or entrepreneurs). Higher Education Headhunter research suggests that only 35 percent of alumni work in the specialty they studied at the university. ${ }^{24}$

The goals and objectives within legal education are changing due to globalization. New competencies are required so that a specialist can work within his/her national

22 Rajni Parmar, Problems and Challenges of Legal Education, 5(9) International Journal of Management and Social Sciences Research 53, 53-57 (2016); The Brazilian Legal Profession, supra note 21, at 190201; Shuvro Prosun Sarker, Empowering the Underprivileged: The Social Justice Mission for Clinical Legal Education in India, 19 International Journal of Clinical Legal Education 321, 321-339 (2015); Pamela N. Phan, Clinical Legal Education in China: In Pursuit of a Culture of Law and a Mission of Social Justice, 8(1) Yale Human Rights and Development Journal 117, 117-152 (2005); B.C. Nirmal, Legal Education in India: Problems and Challenges, 20(1) IIUM Law Journal 139, 139-167 (2012); N.R. Madhava Menon, The Transformation of Indian Legal Education, Harvard Law School Program on the Legal Profession (2012) (Sep. 10, 2018), available at https://clp.law.harvard.edu/assets/Menon_Blue_Paper.pdf; Lovely Dasgupta, Reforming Indian Legal Education: Linking Research and Teaching, 59(3) Journal of Legal Education 432, 432-449 (2010); Carl F. Minzner, The Rise and Fall of Chinese Legal Education, 36(2) Fordham International Law Journal 335, 335-396 (2013).

Legal Education in India: Problems and Perspectives (S.K. Agrawala (ed.), Bombay: N.M. Tripathi, 1973).

24 Кто в России работает по специальности // ИТАР-ТАСС. 8 февраля 2017 г. [Who in Russia Works in the Specialty, Russian Information Agency TASS, 8 February 2017] (Sep. 10, 2018), available at http:// tass.ru/obschestvo/4007168. 
legal system but can also provide relevant legal support for transnational businesses. New requirements for lawyers include the capacity to understand and use foreign legal systems, to practice in different jurisdictions and to work effectively with foreign clients.

Meanwhile, there is no drop in demand for traditional legal services such as, for example, protecting citizens' rights in distant, rural regions. The ever-changing legal market still requires lawyers for law enforcement bodies, and for state, civil and municipal services.

Setting goals and objectives is determined not only by the demand for qualified lawyers with certain specializations, for they also depend on the particularities of the country's historical development. For instance, India, being once a colony of the United Kingdom, inherited its common law system based on the doctrine of judicial precedent. Against this background, the "ideal model" of a lawyer is a judge or an advocate who can be self-regulated and possess membership in a law association. Historically, an advocacy was a family business and a professional did not have to prove his/her qualification with a university certificate or diploma. After gaining its independence from the United Kingdom in 1947, India reformed its legal system and set new requirements for lawyers, such as receiving official legal education and the requirement to pass the bar examination. Still, the main demand in the legal profession is predominantly for practitioners for the local courts, as well as judges or advocates. Indian society has resisted foreign lawyers practicing in the country, though in the larger cities there are several law firms handling corporate work. Family ties are said to play a major role in obtaining legal positions..$^{25}$

In contrast, there is the legal education system in Brazil, which changed its economic policy in the 1990s, opening up new economic opportunities and attracting foreign investment. New processes encouraged rapid development of international legal activities, advanced law firms and high demand for lawyers (advocates). A big influence on the formation of Brazilian law was undertaken by the Portuguese legal culture. Paradoxically, Brazil cut formal ties with Portugal in the mid-nineteenth century and started to develop "new" models of legal practice borrowed from the country's increasing ties with the United States, which, due to its geographic proximity and economic power, exerted considerable influence. By the time Brazil's corporate sector began its rapid development in the 1990s, the American version of the in-house counsel movement was firmly underway. This process has been accelerated by the globalization of knowledge. As a result, Brazil witnessed a growing number of the country's elite lawyers opting to pursue graduate education (including LL.M. degrees and other advanced law degrees) in the United States. Although most of these lawyers started to work in Brazil's increasing number

25 Flood, supra note 15, at 25. 
of elite corporate law firms, some were eventually hired by multinational companies seeking to build more sophisticated internal legal capacity. ${ }^{26}$

The "global shift" leading the BRICS countries to integrate their economies into global markets has seen a growing number of multinational companies set up operations in these increasingly important jurisdictions. Similarly, as multinational companies based in countries such as Brazil and India seek to grow in emerging markets, they emulate a new model of a lawyer. The Brazilian model of an "ideal lawyer" also correlates with the notion of the general role of a lawyer, regardless of the type of activity that he/she is engaged in. The scope of a lawyer's activities is, in particular, to support the democratic development of the country, protect human rights, ensure justice and protect the public interest through legal mechanisms.

India's post-colonial legal elite, by contrast, were introduced to very different legal models. ${ }^{27}$ Lawyers in India are less involved in the activities of large international legal corporations and focus more on domestic practice. Legal education in India has historically been unable to respond meaningfully to contemporary challenges. ${ }^{28}$ Despite various options and suggestions for education reform, there has not been any remarkable change in legal education in India. The Indian legal education system is still not fully prepared to overcome the challenges of globalization. India's rising corporate elite, which continued to look to the United Kingdom for guidance in many fields including law, were slow to embrace the role of sophisticated internal lawyering. ${ }^{29}$

Russia and China have much in common in terms of the context of their perception of "an ideal lawyer" as well as their changing goals in legal education. The Western and Eastern civilizations (Russian and Buddhist-Confucian) have significant differences in regulating social relations, determining a special role for law as a social regulator. Historically, they have usually been described as two models "the Western," where law is the foundation of social behavior. Law is understood as the basic social contract, as a universal and abiding regulator. Its universal character presupposes that law equates everyone and guarantees each person inalienable rights and interprets duties. Within this model, social groups and public authorities are forced to coexist and achieve their goals within legal frameworks.

The other model - "the Eastern" - is based on a hierarchy of social relations, i.e. power. Power generates law, which is considered to be a tool, directed downwards. The source of law is power, which is above law. Law in the East was a will of sacred

26 The Brazilian Legal Profession, supra note 21.

27 Id.

28 Legal Education in India: Challenges and Perspectives 29 (G.M. Rao \& K.S. Rao (eds.), Hyperabad: Asia Law House, 2010).

29 David B. Wilkins \& Vikramaditya S. Khanna, South by Southeast in The Brazilian Legal Profession, supra note 21 , at $94-126$. 
authority, and people could only fulfill the norm sent down from above. In spite of Roman law having been borrowed and codified, the legality of Eastern civilizations was not embedded in "Law," as it was subordinated to the objectives and will of the government. ${ }^{30}$ This is specific to the historical evolution of law in the East.

In the present constitutions of Russia and China (1993 and 1982, respectively) one of the basic principles is the "rule of law," the authority of law in society's relations; nevertheless, in these countries the state bureaucracy dominates all spheres of public life (the economy, culture, social sphere, etc.). Against this background, the perception of a lawyer is a civil servant who performs various types of legal activities. This perception influences the market for lawyers. The explicit example is the master's degree program "International Law, European Law," established at the University of Tyumen, Russia, in collaboration with European universities since 2016, which has failed to be popular with prospective bachelor's students. Whereas one of the master's programs most in demand is the "Legal activities of public authorities."The average annual number of enrolled students is 65 .

Unlike India and Brazil, the public authorities of China and Russia are the only decision-makers that determine the policy of higher legal education. The objectives of legal education institutions frequently change depending on the political course and leadership within these countries. For example, in China two projects targeting higher education expansion were launched in the 1990s - "Project 211" (in the mid1990s) and "Project 985" (in 1998). The result was rapid expansion of legal education which had not taken into account the actual professional or social demand. Rather, it has been a race between schools competing for central recognition. ${ }^{31}$ The goal of legal education in this case seems significantly broader, i.e. to receive higher education that guarantees employment not only with a law firm but also with a multinational company. At the same time, the Chinese government pursued a policy of raising the qualification level of public authorities: a law degree diploma has now become a necessary professional requirement for a judge or lawyer.

Chinese authorities decided to rapidly expand higher education across the board. ${ }^{32}$ In part, this represented a long-range effort (beginning in 1993) to raise the educational level of the working population. During the 1950s, the Communist

30 Винниченко О.Ю. Проблемы реализации права в контексте специфики российской государственности: историко-правовой аспект // Правовое государство: теория и практика. 2014. № 2(36). C. 8 [Oleg Yu. Vinnichenko, Problems of the Implementation of Law in the Context of the Specifics of Russian Statehood: The Historical and Legal Aspect, 2(36) Rule of Law: Theory and Practice 6, 8 (2014)].

31 Minzner 2013.

32 Id. at 345; Yinmei Wan, Expansion of Chinese Higher Education Since 1998: Its Causes and Outcomes, 7(1) Asia Pacific Education Review 19, 19-31 (2006); Yuzhuo Cai, Chinese Higher Education: The Changes in the Past Two Decades and Reform Tendencies Up to 2020 in China and Brazil: Challenges and Opportunities 91, 91-118 (L. Ferreira \& J.A. Guilhon Albuquerque (eds.), São Paulo: Annablume, 2013); Tamar Lewin, Study Abroad Flourishes, With China a Hot Spot, The New York Times, 17 November 2008 (Sep. 10, 2018), available at https://www.nytimes.com/2008/11/17/education/17exchange.html. 
Party of China (CPC) reformed legal education to meet this vision. The existing law departments were reorganized. Some became politics and law (zhengfa) institutes managed by the Ministry of Justice which produced graduates to serve as frontline state cadres in government and judicial institutions throughout the new socialist China. ${ }^{33}$ Others became departments within universities, such as Peking University, focusing on training elite researchers and officials. Naturally, all were part of broader state efforts to create an institutionalized system of higher education, albeit a politicized one under firm Party control. ${ }^{34}$ Legal studies consisted of reading political works, translating Russian-language papers, and new laws issued by China's nascent national legislature. Since 1978, Chinese legal education has been intimately tied to new institutional reforms. Law schools emerged as a somewhat protected zone for criticism and discussion of contested political issues, and in the 1980s legal education was offered by a diverse range of institutions. The Ministry of Justice and political-legal institutes ran short-term cadre training programs on new laws and legal concepts for courts, police and the procurator service, ranging anywhere from one to six months in length..$^{35}$ Chinese authorities granted school administrators more autonomy to manage the regular operations of their institutions. They also adopted new funding mechanisms. Central authorities significantly increased the resources available for higher education. At the same time, the main focus of law students' training was preparing for the employment exam for public service. ${ }^{36}$

Much attention was paid to the openness of the education system to world achievements and research. China sponsored highly ranked scientific journals and hosted large international conferences that became the most important indicator of the country's innovative development.

Since 2011, a new legal education policy has been proclaimed in China, based on the idea of "socialist rule of law" and the preservation of the national approach to education. ${ }^{37}$ Legal educational institutions were differentiated according to their specialization: (a) to support international transactions; (b) to perform legal practice; (c) to work as lawyers in rural areas. Thus, there was a change in the objectives of legal education in terms of a differentiated approach in training for future professional activities, taking into account the national specific features of China and the need for social development. ${ }^{38}$

33 Minzner 2013, at 341.

34 Barry Sautman, Politicization, Hyperpoliticization and Depoliticization of Chinese Education, 35(4) Comparative Education Review 669, 670 (1991).

35 Timothy Gelatt \& Frederick Snyder, Legal Education in China: Training for a New Era, 1 China Law Report 41, 54-55 (1980).

36 Minzner 2013, at 345.

37 Джуринский А.Н. Высшее образование в современном мире: тренды и проблемы [Alexander N. Dzhurinsky, Higher Education in the Modern World: Trends and Problems] 25 (Moscow: Prometey, 2017). 
Legal education in Russia has taken a very similar developmental path for the last twenty years. Laws and other legal acts of the 1990s to the early 2000 s set certain requirements, for example, publication activity, a massive character and a focus on quantitative indicators. The general state policy was to transform all national universities into research institutions. ${ }^{39}$

Internationalization has been a focus of Russian universities since early 2000. In September 2003, Russia joined the Bologna Declaration, aimed at harmonizing European education standards. The main responsibilities of Russia were to change its system of higher education, share European educational values and promote social approaches in higher education in order to make it accessible to most citizens. Yet, there is no consensus among those in Russia's academic community as to whether the move was justified. For example, a large number of courses with a general education component is disputable. Russian educational traditions as well as gaps in general secondary education reinforce the problems of law schools and as a result universities were forced to teach general educational aspects rather than focus on professional disciplines. One sociological survey pointed out one of the main deficiencies of higher education in Russia:

Currently, the universities are fulfilling the task of continuing high school education. Applicants do not possess basic skills of working with information (reading text, understanding the text, generalization, retelling, etc.). As a result, de facto universities have to teach freshmen core subjects before "they are ready for legal disciplines."40

Since 2010, the Russian Federation has been changing their priorities in legal education. Internationalization, the export of education services and student exchange activities have become the main priorities. The focus of training has been shifted to

39 Закон Российской Федерации от 10 июля 1992 г. № 3266-І «Об образовании», Собрание законодательства РФ, 1992, № 3, ст. 150 [Law of the Russian Federation No. 3266-I of 10 July 1992. On Education, Legislation Bulletin of the Russian Federation, 1992, No. 3, Art. 150]; Федеральный закон от 10 апреля 2000 г. № 51-Ф3 «Об утверждении Федеральной программы развития образования», Собрание законодательства РФ, 2000, № 16, ст. 1639 [Federal Law No. 51-FZ of 10 April 2000. On Approval of the Federal Program for the Development of Education, Legislation Bulletin of the Russian Federation, 2000, No. 16, Art. 1639]; Федеральная целевая программа развития образования на 2006-2010 годы, Собрание законодательства РФ, 2006, № 2, ст. 186 [Federal Targeted Program for the Development of Education for 2006-2010, Legislation Bulletin of the Russian Federation, 2006, No. 2, Art. 186]; Распоряжение Правительства Российской Федерации от 29 декабря 2001 г. № 1756-р «О Концепции модернизации российского образования на период до 2010 года», Собрание законодательства РФ, 2002, № 1, ст. 119 [Order of the Government of the Russian Federation No. 1756-p of 29 December 2001. On the Concept of Modernizing Russian Education for the Period Until 2010, Legislation Bulletin of the Russian Federation, 2002, No. 1, Art. 119].

40 Юридическое образование: поиск новых стандартов качества. Материалы исследования [Legal Education: Search for New Quality Standards. Research Materials] 29 (Moscow: Institute of Public Interest Law, 2013). 
the competencies demanded by investigators, prosecutors, judges and officials of public authorities. ${ }^{41}$ The Rector of Moscow State Law University (one of the leading law schools in the country) Viktor Blazheev in an interview described this goal explicitly. In his opinion, a valuable graduate of a law school should be"a comprehensively trained and practice-oriented lawyer focused on a certain law field."42

Clear evidence of a state policy shift in higher legal education is the partial return to the previous training system called "specialist" (five years of study). Alongside the European-patterned system of a bachelor's degree (four years) and a master's degree (two additional years), more and more law schools suggest majors in "national security," "judge and prosecutor," "law enforcement authorities" for the five-year study period. This trend corresponds to law school reforms in China after 2010 and correlates with Russian Federation priorities.

Russian legal education and science are still rather closed. In China, for example, the world's education and research achievements are visible and accessible for students, which allow them to develop in the context of world trends. In Russia, as Dmitry Maleshin, a professor at Moscow State University, noted, "The remoteness of the national higher law school is turning into a big problem." The thirty-year period of expanding international cooperation of Russian domestic universities shows that Russian law schools understand internationalization more often as an exchange of delegations, students, joint conferences. Joint educational programs or curricula as well as joint research projects are lacking in Russian law schools. ${ }^{43}$ Russian law schools are focused on training mainly for domestic needs. Training for legal support for transnational transactions, which is on the rise within the international community, can hardly be found in Russia. Whereas foreign law schools provide exchange and internships abroad for their students, it is only the elite Russian educational institutions that have such an option.

41 Федеральный закон от 29 декабря 2012 г. № 273-Ф3 «Об образовании в Российской Федерации», Собрание законодательства РФ, 2012, № 53, ст. 7598 [Federal Law No. 273-FZ of 29 December 2012. On Education in the Russian Federation, Legislation Bulletin of the Russian Federation, 2012, No. 53, Art. 7598]. See also Распоряжение Правительства Российской Федерации от 15 мая 2013 г. № 792-р «Об утверждении государственной программы РФ «Развитие образования» на 20132020 гг.», Собрание законодательства РФ, 2013, № 21, ст. 2671 [Order of the Government of the Russian Federation No. 792-r of 15 March 2013. On Approval of the State Program of the Russian Federation “Development of Education" for 2013-2020, Legislation Bulletin of the Russian Federation, 2013, No. 21, Art. 2671].

42 Горожанина Н., ЧестноваЮ. Интервью к 85-летию МГЮА имени О.Е. Кутафина с сопредседателем ассоциации юристов России, ректором Московского государственного юридического университета имени О.Е. Кутафина Виктором Блажеевым // Юридический мир. 2016. № 11. С. 7 [N. Gorozhanina \& Yu. Chestnova, Interview to the $85^{\text {th }}$ Anniversary of the Moscow State Law University named after O.E. Kutafin with the Co-chairman of the Association of Lawyers of Russia, Rector of the Moscow State Law University named after O.E. Kutafin Victor Blazheev, 11 Legal World 6, 7 (2016)].

43 Малешин Д.Я. Вызовы для современной высшей школы // Закон. 2014. № 1. С. 35 [Dmitry Ya. Maleshin, Challenges for Modern Higher Education, 1 Law 29, 35 (2014)]. 
To summarize, the goals of legal education in BRICS vary and depend on different country backgrounds - globalization processes, the specifics of domestic demand for the legal professions, economic development, national legal systems, state education policy and society's perception of a lawyer's competencies. Shifts in these factors foster changes in the goals and objectives of legal education.

Four BRICS countries demonstrate some common features in legal education expansive reforms and unjustified shifts in goals and objectives. Changing objectives of legal education are manifested in training certain types of specialists with limited competencies, and also in transforming legal schools into two types -"elite universities," not affordable for everyone, and "ordinary institutions." Mass legal education is significantly expanded and has become a typical feature of education systems in BRICS countries.

The goals, quality and outcome of education in the two types of law schools are very different. This situation is typical for all BRICS countries and is associated, to a large extent, with income society stratification.

The goals and objectives instigate the structure and requirements for quality legal education in the BRICS countries. This is discussed in the next sections.

\section{Structure of Legal Education at the Universities of Brazil, India, China and Russia}

The structure of legal education in BRICS has been determined by the globalization process and has taken much from the American and European education systems, at the same time the implementation of the educational objectives of BRICS has resulted in some reforms of higher education as well as the changing roles of government and non-governmental organizations. The structures of legal education in Brazil, India, China and Russia share similar features as well as specifics conditioned by many external and internal factors.

\subsection{Brazil}

The system of higher legal education in Brazil includes both public (in federal, state and municipal districts) and private educational institutions (which can also receive state funding). Public education is free; however, 87 percent of educational legal institutions are private schools. ${ }^{44}$ Higher legal education has several stages. The first stage lasts five years and ends with a bachelor's degree, which is deemed sufficient to take the Brazilian Bar Exam. Master's degree programs last two additional years with a master's thesis requirement. To obtain a doctoral degree, one should study for a further four years, successfully pass the qualification exam, and write

44 The Brazilian Legal Profession, supra note 21, at 193. 
a doctoral dissertation. Briefly, the system of legal education in Brazil can be characterized by the scheme: $5-2-4 .{ }^{45}$

Private law schools are supported by the government. Social demand for university degrees has provided an option for mass education, usually coupling low fees, low wages for teachers, little or no concern for academic research and uncertain overall educational quality. These new law schools are not primarily concerned with training new legal professionals, let alone corporate or global lawyers. Most of their alumni have dismal results at the bar exam, but this does not prevent these law courses from continuing to be attractive for those in search of certification rather than professional training. ${ }^{46}$

Since the 1990s there have been new attempts to change law schools - by the phenomenon of an increasing number of continuing legal education programs (CLE, known as lato sensu graduate certificate courses). Outside the reach of the Ministry of Education's strict regulations, such courses attract a large number of undergraduates who are clearly aware of the inadequacies in their legal knowledge, despite certificates and bar membership. CLE courses have become a prime locus for the formation of corporate lawyers in Brazil. Unlike law schools, which remain for the most part faithful to their traditional syllabi, the curricula of the CLE clearly display concern with the impact of globalization on the practice of law in the country. CLE has become one of the new frontiers in the debate on legal education in Brazil. ${ }^{47}$

Much smaller in size but much more revealing in design is the phenomenon of "in-house training," which has become trendy among the top law firms in the country. Disappointed by the legal training that most law schools and CLE institutions offer, some of the most prestigious law firms in Brazil have started programs to train their own personnel. These corporate courses have become much more common in the large law firms in São Paulo and Rio de Janeiro, and it is thought that there are around 300 such in-house programs throughout the country. Like the CLE programs, these courses are also outside the scope of official regulation. ${ }^{48}$

\subsection{India}

The modern system of legal education in India is very difficult to understand from the outside. This is due to the legacy of British colonialism, making it a multilevel and complex educational structure. There are 900 to 1,000 law colleges and universities

45 Образование в Бразилии - краткий экскурс // StudyGlobe.ru [Education in Brazil - A Short Survey, StudyGlobe.ru] (Sep. 10, 2018), available at http://studyglobe.ru/countries/Brazilija/.

46 The Brazilian Legal Profession, supra note 21, at 247-263.

47 Id. at 280 .

48 Cláudio de Moura Castro \& Marisa Eboli, Universidade Corporativa: gênese e questões críticas rumo à maturidade, 53(4) Revista de Administração de Empresas 408, 408-414 (2013). 
in the country. They fall into three categories: private global law schools, national law schools and parochial law colleges, many of which are privately run. ${ }^{49}$

In India, national law universities and law colleges offer a three-year bachelor's law degree and a five-year integrated undergraduate degree. Most public and private colleges are affiliated with universities that provide predominantly master's degree programs. Universities are mostly public institutions and are responsible for regulating the education process in colleges that receive accreditation through their programs. Public universities award the qualification to the graduates.

The current policy of the Bar Council of India (BCI), which is the supreme regulatory body of the legal profession in the country and prescribes the curricula and syllabi for undergraduate courses, has been to encourage five-year, dual degree LL.B. programs. $A$ recent legal education reform is moving forward to a five-year dual degree LL.B. program recognized by $\mathrm{BCl}$, but at the same time $\mathrm{BCl}$ continues to encourage three-year bachelor's programs for specialized areas such as Intellectual Property Rights, which are undertaken by postgraduates. The curriculum prescribed by $\mathrm{BCl}$ for each of the degree programs is mandatory for all law colleges and university departments of law. ${ }^{50}$

Legal clinics as a special form of legal education became very popular in educational institutions and Indian society despite the fact that this method of training lawyers was borrowed from the United States. The experience of Indian legal clinics is summarized in national studies and has been successfully implemented throughout the country. ${ }^{51}$ With a large number of socially disadvantaged citizens in India, clinics provide free legal assistance to those in need, and also introduce students to the ideas of social justice and the importance of the law. It is interesting to note that all BRICS countries adopt these principles in the education process when preparing lawyers..$^{52}$

Legal education in India requires a new technique of restructuring to avoid repeating earlier futile experiments..$^{53}$

\subsection{China}

Higher legal education in the People's Republic of China, unlike in India, has a fairly clear structure and is regulated by state authorities. The American model of higher

49 John Varghese, Global Legal Education and India - A Blueprint for Raising Indian Legal Education to Global Standards (2010) (Sep. 10, 2018), available at http://papers.ssrn.com/sol3/papers. cfm?abstract_id=1728451.

50 Nirmal 2012.

51 David W. Tushaus et al., India Legal Aid Clinics: Creating Service Learning Research Projects to Study Social Justice, 2(2) Asian Journal of Legal Education 100 (2015).

52 Phan 2005.

53 Dasgupta 2010; Shamnad Basheer \& Sroyon Mukherjee, Regulating Indian Legal Education: Some Thoughts for Reform (2010) (Sep. 10, 2018), available at https://ssrn.com/abstract=1584037. 
education has become a basic pattern for Chinese universities. All higher education institutions there are divided into universities and other educational institutions such as political and legal, technical, agricultural, pedagogical institutions and so on. They are classified according to their reputation and hierarchy; for example, some educational institutions are subordinated to central departments and some to regional ones. ${ }^{54}$

From the 1990s to the beginning of the 2000s higher legal education in China exploded. For instance, the national educational projects " 211 " and "985" contributed to the rapid growth of higher education institutions in law. The total number of law graduates from Chinese institutions of higher education surged from 31,500 in 1999 to 163,529 in 2005 , and to 208,000 in 2008 . Legal education increased proportionally as well. In 1988, law graduates accounted for only two percent of all graduates from institutions of higher education. By 2001, this share had tripled to six percent. ${ }^{55}$

In 2011, a new education policy called the "Outstanding Legal Talent Training Program" was launched redesigning law schools into three different types: (1) those that are generally focused on improving students' practical skills, (2) those that train elite students to operate in the global economy, and (3) those that train basic-level legal personnel for the courts and governmental agencies of rural western China. Some eighty institutions are to be designated under the first category. Twenty are to receive the designation for their work on globalized legal education; twenty for their work on training rural cadres..$^{56}$

In China, there are three levels of legal education: bachelor's degree, master's degree and doctoral studies. Earlier specialization of students is provided through flexible programs. The term of the bachelor's program is four years, two to three additional years for the master's degree, plus three more years in doctoral studies. This is a 4-2(3)-3 model. The bachelor's program may include a significant number of nonlegal courses. An academic master's (faxue shuoshi) coexists along with a practical (professional) master's (faltoblayder shuoshi). The degree of practical master was introduced in the 1990s by the Ministry of Justice with the goal of training personnel for this department, and it is a Chinese feature of higher legal education.

\subsection{Russia}

The system of higher legal education in the Russian Federation combines comprehensive universities, specialized universities, ${ }^{57}$ federal universities and research

54 Susan P. Robinson, Higher Education in China: The Next Super Power is Coming of Age (Washington: American Council on Education, 2005).

55 Minzner 2013, at 350.

56 Id. at 373.

57 Kutafin Moscow State Law University; Ural State Law University; Saratov State Law Academy; eighteen educational institutions of the Ministry of Internal Affairs of the Russian Federation, including the St. Petersburg University of the Ministry of Internal Affairs of the Russian Federation, the Nizhny Novgorod Academy of the Ministry of Internal Affairs of the Russian Federation. 
universities. The last two types of universities are not numerous and are in a privileged financial position.

Russia is not exceptional among the leading countries and does not have a tradition of private universities. The new emerging market in Russia changed the face of higher education. By 2015, the share of private higher schools out of all Russian universities was about 45 percent. The total number of students in "paid" education grew to over 60 percent. However, public universities have the right to undertake commercial activities. In the system of higher education new stakeholders have appeared; these include student family members, students themselves and employers.

In Russia, the rise of legal education took place in the 1980s and 1990s. From about 500 public universities, the number rapidly grew because of the appearance of private universities. By the beginning of the 2013-2014 academic year there were about 2,500 universities in Russia. In the twenty years 1990-2010 the annual number of students in Russian universities increased from 2.8 million to 7 million. ${ }^{58}$

"Jurisprudence" was one of the first popular areas of studies. The Association of Russian Lawyers reported that the number of law schools and departments had grown twenty-one times between 1991 and 2010. Immediately after the collapse of the U.S.S.R., only fifty-seven universities and law schools were opened in the country with a population of 280 million people. In modern Russia, the population is approximately 145 million, and the number of universities in 2010 was 1,200. Legal education at the time acted as a specific means for the universities to earn money in conditions of limited state funding. Law departments opened on a broad scale, not just in comprehensive universities, but also in non-core universities - engineering, agrarian, military and others. With the shortage of competent staff, legal disciplines were often taught by former policemen or teachers across three to five universities. As a result, in the early 2000 s the problem with the quality of legal education was widely discussed within the Russian legal community. ${ }^{59}$

To implement the requirements of the Bologna Declaration, since 2009 there has been a transition to a multilevel structure of higher education. The universities design the education process in tiers: bachelor's degree (four years) and master's degree (two additional years). Previously, there was the training of legal cadres through a specialty system (five years), within the framework of which students received more comprehensive training in certain areas of the law (criminal law, civil law, public law).

The bachelor's degree is officially considered the first stage of completed higher legal education, but the reduction in the period of study from five to four years has adversely affected the quality of the practical skills of graduates. Graduates

58 Dzhurinsky 2017, at 8.

59 Актуальные проблемы российского права и высшего юридического образования в современных условиях развития государства [Actual Problems of Russian Law and Higher Legal Education in the Current Conditions of State Development] (S.V. Alekseev (ed.), Penza: RIO PGSKhA, 2004). 
of bachelor's degree programs in Russia find difficulties with their employment because their employers are not satisfied and sometimes do not even understand their bachelor's qualification. Employers consider a bachelor's degree student to be an "incomplete, half-trained specialist," disconnected from reality and requiring additional training. ${ }^{60}$

Prior to 2012, training for the legal professions in Russia was carried out through postgraduate and doctoral studies, which were considered elements of the postgraduate education system. The outcome was a doctoral dissertation and the degree of "candidate of law" (Doctor of Law). Federal law of 29 December 2012 No. 273-FZ "On Education in the Russian Federation" included postgraduate study (three-four years) in the third stage of higher education. ${ }^{61}$ Thus, the system of higher legal education was organized into: four years (bachelor degree) - two additional years (master's degree) or five years (specialty) - three to four years (postgraduate study). A doctoral degree could be obtained by graduating from a doctorate program or by attaching a candidate to one of the leading universities. However, now doctoral studies are not included in the system of higher legal education and have the status of a special "form of training researchers."162

Russia is one of the few countries in the Bologna Process where the Soviet system of scientific degrees and titles has survived. Today, the country faces a period of transition to the European-American system of degrees and ranks. There is a risk that in this transition, the degree of "doctor of law" will be devalued in terms of the quality of its dissertational research. ${ }^{63}$

Recently, the need for education reform has been mentioned in a plethora of regulatory acts, outlining reform tools and the means for improving the quality of the education process. ${ }^{64}$ Strategies in state education policy have been recently defined. For instance, the system of higher education has been substantially updated - it includes federal and national research universities and other universities which were considerably restructured. Uncontrolled growth of commercial schools

Милованова Н. 4+2=? // Российская газета. 11 октября 2005 г. [Natalya Milovanova, 4+2=?, Russian Gazette, 11 October 2005] (Sep. 10, 2018), available at https://rg.ru/2005/10/11/bakalavr.html.

Federal Law No. 273-FZ, supra note 41.

62 Положения о докторантуре», Собрание законодательства РФ, 2014, № 15, ст. 1759 [Decree of the Government of the Russian Federation No. 267 of 4 April 2014. On Approval of the Regulations on Doctoral Studies, Legislation Bulletin of the Russian Federation, 2014, No. 15, Art. 1759].

63 Постановление Правительства Российской Федерации от 24 сентября 2013 г. № 842 «О порядке присуждения ученых степеней», Собрание законодательства РФ, 2013, № 40 (ч. 3), ст. 5074 [Decree of the Government of the Russian Federation No. 842 of 24 September 2013. On the Procedure for Awarding Academic Degrees, Legislation Bulletin of the Russian Federation, 2013, No. 40 (part 3), Art. 5074].

64 Federal Law No. 51-FZ, supra note 39; Federal Targeted Program for the Development of Education for 2006-2010, supra note 39. 
and universities and corruption in higher education institutions have been put under scrutiny, controlled and prevented where possible. In the same period, new educational technologies have been developed and there has been an expansion in exports of education services. Particular attention is paid to state and public control over educational institutions and the maintaining of and adherence to quality standards.

The result of new education policies is the process of law school differentiation into "elite" schools, with a high quality of education, and "mass" schools that satisfy the demand of the majority of the population but where students obtain higher education qualifications with insignificant quality. This trend is most indicative in China and Russia, although in general it is typical for all BRICS countries.

\section{Conclusions on the Structure of Legal Education}

Global processes in education impact the structure of legal education in the BRICS countries; BRICS are seen to be mostly adhering to the American pattern of education albeit with some national aspects.

The structure of legal education in Brazil is characterized by a wide range of programs of continuous legal education and corporate courses that fill the gaps left by mass education. Legal education in India has a complex, multilevel structure associated with British influence.

The development of the Chinese legal education system evidences the attempts to borrow similar experiences from American and British educational systems. The result is a structural reform of higher education to provide an effective response to internal and external challenges. In Russia, similar processes are observed, but are delayed in their implementation. In both countries, the influence of the political situation and the dominance of public bodies have a significant impact on these processes.

\section{Quality of Legal Education in India, Brazil, China and Russia}

The issue regarding the quality of legal education is a hot topic not only for BRICS, but also for leading countries - such as the United States and Great Britain. For example, the legal education crisis is regularly discussed in the U.S.A. with reforms being implemented every ten to fifteen years. ${ }^{65}$ It is not a new phenomenon that both faculty and students around the world are subjected to changes invoked by

65 Legal Education Reform, The New York Times, 26 November 2011 (Sep. 12, 2018), available at https:// www.nytimes.com/2011/11/26/opinion/legal-education-reform.html; Harold J. Berman, The Crisis of Legal Education in America, XXVI(2) Boston College Law Review 347, 347-352 (1985); Arthur Kinoy, The Present Crisis in American Legal Education, 24 Rutgers University Law Review 1 (1969). 
reforms and revision of education traditions and teaching methods. However, the former approaches are unable to meet the current needs and demands, thus their transformation is currently underway. This fact illustrates the transition to a higher law school and its search for a new role in a changing world. ${ }^{66}$ For the same reason, improvements in the quality of education are a continuous process echoing the challenges of a changing domestic and global society.

The methodology of our research in regard to the quality of legal education is adapted from research and practitioner literature in the field. ${ }^{67}$ We measured and compared basic elements, including: quality standards, sources of standardization, normative regulations of the education process and its content and control over quality standards.

Quality standards in each of the BRICS countries are individual and implemented in the context of the national legal systems. This means that Brazil, Russia, India and China have their own systems of quality standards including specific regulations on the education process as well as monitoring schemes that are applied within a specific education system. Firstly, we focus on the definite features of each country in the BRICS group. Secondly, we outline typical elements that demonstrate the quality of legal education within each of the BRICS countries.

Similar to the first part of the paper, we compare the attempts made by India and Brazil in formulating analogous objectives of legal education and their countryspecific standards of quality. The two countries can be contrasted because selfgoverning bodies of law as well as private companies play a significant role in both.

\subsection{India}

Traditionally, the standards of legal education are set by the $\mathrm{BCl}$ which principally regulates formal legal education. The $\mathrm{BCl}$ works under the observation of the Supreme Court; the $\mathrm{BCl}$ is the highest professional body in India. According to the Advocates Act 1961, the BCl supervises the law schools in the country ${ }^{68}$ and lays down standards of legal education in consultation with Indian universities delivering such education. All issues relating to admissions, practice, ethics and standards are addressed by the $\mathrm{BCl}$ in accordance with State Bar Councils. The powers of the $\mathrm{BCl}$ are also envisioned under the Advocates Act 1961 and Bar Council of India Rules 1965 , according to which the $\mathrm{BCl}$ deals exclusively with the minimum standards of legal education. ${ }^{69}$ In 1962, following BCl orders, all universities imparting legal education revised their curricula and transitioned from a two-year to a three-year

66 Maleshin 2014, at 30.

67 Legal Education, supra note 40, at 167-175; see also Minzner 2013.

68 Parmar 2016, at 53; The Bar Council of India, Part IV, Rules of Legal Education (2008) (Sep. 12, 2018), available at http://www.barcouncilofindia.org/wp-content/uploads/2010/05/BCIRulesPartIV.pdf.

69 Scenario of Legal Education in India, supra note 68, at 132. 
program in law. ${ }^{70}$ Market mechanisms are also important, for instance, in the case of non-compliance with these requirements, educational institutions become less competitive and experience a reduction in student enrollment.

The University Grants Commission (UGC), founded in 1956 to develop higher education in India, operates as an umbrella organization for all institutions of higher education. ${ }^{11}$ The main aim and role of the UGC is to provide funds to universities and coordinate, determine and maintain their ethics. The commission upholds the interpretation of ethics among universities, government and the community. The UGC has also set standards and procedures for universities that strive to become "UGC-Approved Universities." "72

Standards of legal education are laid down by the $\mathrm{BCl}$ in accordance with recommendations made by its Legal Education Committee after consultation with the State Bar Councils and the Legal Education Committee of the UGC. Moreover, their rules can be challenged in the Supreme Court, which can strike down the standards or other requirements in order to maintain unified standards or if they conflict with human rights principles. ${ }^{73}$

The National Knowledge Commission (NKC) was constituted in 2005 as an advisory body to the Prime Minister of India on education. It was a new step in legal education reform. In 2010, the Curriculum Development Committee (CDC) was established to emphasize faculty autonomy in designing and conducting law schools' curricula. It supervises program design and study materials with the aim of keeping the curriculum dynamic and ensuring the appropriate methodology of teachinglearning is adopted, and that a specific standard is achieved by the students..$^{74}$ In 2010, the $\mathrm{BCl}$ established a Directorate of Legal Education for the purpose of organizing, running, conducting, holding and administering (a) continuing legal education, (b) teachers training, $(c)$ advanced specialized professional courses, $(d)$ an education program for Indian students seeking registration after obtaining a law degree from a foreign university, $(e)$ seminars and workshops, $(f)$ legal research and $(g)$ any other assignments. ${ }^{75}$ They are responsible for setting minimum requirements for the education process, curricula and library resources. ${ }^{76}$

70 Scenario of Legal Education in India, supra note 68, at 135-136.

71 Kashyap 2016, at 141-142.

72 G. Abhilasha, What Is UGC? All About Its Establishment, Functions, and Structure, Eduncle, 29 June 2018 (Sep. 10, 2018), available at https://scoop.eduncle.com/about-university-grants-commission.

73 The Bar Council of India, Legal Education (2018) (Sep. 10, 2018), available at http://www.barcouncilo findia.org/about/legal-education/.

74 The Bar Council of India, Report of the Curriculum Development Committee (CDC) (2010) (Sep. 10, 2018), available at http://www.barcouncilofindia.org/wp-content/uploads/2011/08/cdc-report-web.pdf.

75 Scenario of Legal Education in India, supra note 68, at 135.

76 Nirmal 2012, at 164-166. 
The quality of legal education is correlated with students' involvement in practical activities. For this purpose, the $\mathrm{BCl}$ adopted a resolution in 2009 , based on the recommendations of the Supreme Court's three-member committee, to set up legal aid clinics in every law school so as to provide an inexpensive and speedy service to underprivileged groups in society. This was a mandatory requirement, serving as a starting point for a formal system, giving law schools a very good opportunity to build their legal aid programs in line with the requirements of the local community. ${ }^{77}$ It affirmed the need for a multi-client-based legal aid program for every community. ${ }^{78}$

The key element of legal education quality in India is a mandatory "All India Bar Examination" which was introduced by the BCl in its Resolution of 10 April 2010. Passing this exam entitles the advocate to a Certificate of Practice which would permit him/her to practice law. The $\mathrm{BCl}$ is vested with the power to lay down conditions of the All India Bar Examination. ${ }^{79}$

Despite the efforts of the government and public authorities in India in improving the quality of legal education, the goals set for the internationalization of the education process and legal practice have not been successfully attained. Law schools have not made many achievements in terms of the creativity of education, research and the unification of requirements and control in the education process. Out of over 1,000 national law schools only a handful have managed to attain the standard required, of which all are orientated towards the American educational model. ${ }^{80}$ The expert position is that: Quality in Indian legal education is an omnipresent problem which they try to solve by multifold commissions, governmental bodies and other bodies such as the NKC - though with little effect. With this in mind, the $\mathrm{NKC}$ recommended drastically reducing the influence of the $\mathrm{BCl}$ in order to improve teaching quality and research, and to begin to internationalize law schools.

\subsection{Brazil}

The case of Brazil is quite different due to the key stakeholder in legal education being the government. However, the Brazilian Bar Association (OAB), a professional association of lawyers, plays an important role in designing legal education on the national level. The curricula in both public and private law schools are regulated by the Ministry of Education, which by means of the Education Guidelines Act (Act N 9,394/96) defines prerequisites across the entire Brazilian territory, regardless

77 The Bar Council of India, Inspection Manual 2010: Guideline for Inspection of Bar Council of India of University/Institution (2010) (Sep. 10, 2018), available at http://www.barcouncilofindia.org/ wp-content/uploads/2010/06/Inspection-Manual2010.pdf.

78 Sarker 2015.

79 The Bar Council of India, All India Bar Examination Rules (2010) (Sep. 10, 2018), available at http:// www.barcouncilofindia.org/all-india-bar-examination-rules-2010-notified/. 
of region. ${ }^{81}$ The federal government regularly makes efforts to design and enforce mandatory quality-enhancing strategies for legal education. The minimum required curriculum for law schools is directly regulated by the National Education Council, a body of the Ministry of Education. The most recent regulations were published in 2004. They actually list the subjects that should be offered in law schools and establish and develop strong guidelines concerning the minimum content requirements skills that should be developed within the law curricula suggested by law schools.

Students in the fifth year of a bachelor's law degree program from a Brazilian school recognized by the Ministry of Education may take the Brazilian Bar Exam, which is mandatory for those who want to work as an attorney. According to some critics, most colleges prioritize training students for the exam rather than educating them for legal work. This exam is also a requisite for most other high-level government positions, such as a judge or a prosecutor. The exam is held nationwide three times a year and has two phases. The first phase is eliminatory and focuses on professional knowledge of the law in all areas. The second tests professional skills in a specific area of law, which the candidate selects upon registration. The areas available in the second phase include: administrative, civil, constitutional, corporate, criminal, labor and tax law. The format of this exam demands very little in terms of skills such as context analysis and legal creativity that are essential for international lawyers. As approval is key to surviving in an especially competitive education market, institutions are understandably averse to changes that do not rely on the bar exam as a basis to organize curricula and methodologies. ${ }^{82}$

The quality of legal education is also measured by means of the National Exam for the Assessment of Student Performance (ENADE). This exam is mandatory for all graduating students. When students enter the course, they take the exam in order to measure expected performance. ENADE is a triennial exam mandatory for senior students during the year of their graduation. Students' professional knowledge, competencies and skills are assessed by their average score. The present system has been running since 2004, serving as criteria for the accreditation of programs and institutions and has been used to regulate the growing private sector of Brazilian higher education, including law schools. ${ }^{83}$

The large number of programs and their geographical concentration have influenced the federal government to become the centralizing figure behind regulation, often in dialogue with the OAB. To help students choose between a variety of programs, the $O A B$ has designed a quality certificate awarded to those programs believed to meet minimum standards. Of almost 1,200 law programs in the

81 The Brazilian Legal Profession, supra note 21, at 193.

82 Id.

83 Renato H.L. Pedrosa et al., Assessing Higher Education Learning Outcomes in Brazil, 24(2) Higher Education Management and Policy 55, 55-71 (2013). 
country only eighty-four (around 7\% of the total) were deemed worthy of receiving the OAB Recomenda certificate in 2015. ${ }^{84}$

The experience of Brazilian public institutions in control of legal education quality is worth mentioning. Apart from the OAB Exam approval rate, law schools are also assessed according to three rankings that monitor the quality of university courses in general. The rankings are determined by: the National Institute for Educational Studies and Research (INEP) ${ }_{1}^{85}$ the São Paulo-based newspaper Folha de São Paulo and by the Guia do Estudante, a prestigious annual magazine devoted to offering candidates in-depth information about major universities in the country. ${ }^{86}$ Taken together, these rankings function as the benchmark for students to decide on which law school to apply to and for employers to assess the quality of the academic background of candidates. The growing importance of these rankings notwithstanding, family ties and attendance at prestigious traditional law schools (regardless of the teaching being offered there) still function as a decisive element in the competition for jobs in the legal services market. ${ }^{87}$

São Paulo and Rio de Janeiro represent a radical breakaway from the traditional organization of law schools. The adoption of student-centered, case-based methodology rather than lecturing and glossing has led them to become a benchmark in discussions on the future of legal education in the country. ${ }^{88}$

Despite significant efforts of the national government to monitor the quality of legal education, the legal community in Brazil believes most law schools are failing to deliver in the light of new challenges, especially as regards their use of traditional curricula and outdated methods in training future lawyers:

Corporate law firms and global corporations' offices sought lawyers with basic legal skills, knowledge of advanced areas of corporate and international economic law, familiarity with global lawyering styles, and a grasp of business fundamentals. Brazilian law schools failed to respond to this demand. With minor exceptions, the established law schools resisted changes. While a wave of new law schools was created, often by profit-seeking institutions, these new entrants concentrated on low-level, mass legal education, replicating traditional curricula and focusing on preparation for the bar exam. While a few law schools in Rio and São Paulo have introduced innovative undergraduate

\footnotetext{
84 The Brazilian Legal Profession, supra note 21, at 194

85 National Institute for Educational Studies and Research "Anísio Teixeira" (Sep. 10, 2018), available at http://portal.inep.gov.br/about-inep.

86 The Brazilian Legal Profession, supra note 21.

87 National Institute for Educational Studies and Research, supra note 85.

88 The Brazilian Legal Profession, supra note 21, at 256.
} 
law programs and addressed global issues, the mass of law schools failed to respond to the new needs. ${ }^{89}$

Nonetheless, traditional law schools in Brazil have an important social function: they provide accessible higher legal education for society through budgetary funding. However, these law schools' graduates lack career prospects. The traditional model of legal education, which exists in parallel with the advanced universities, meets the needs and expectations of Brazilian society; this phenomenon is a manifestation of a rapidly developing Brazilian society.

\subsection{China and Russia}

For China and Russia, regulation and control of the education process and quality standards are undertaken primarily by governmental bodies. In China, the relevant authorities are the Ministry of Education ${ }^{90}$ and the Ministry of Justice; ${ }^{91}$ in Russia it is the Ministry of Education and Science..$^{92}$ The Chinese model is comparable with education management in India - for example, the sharing of responsibility for legal education quality between $\mathrm{BCl}$ and UGC. The difference in the Chinese model is the division of power between public authorities, where some educational institutions are operated by state and local governments.

Since 1998, China's authorities in education have enforced a mandatory core curriculum, which includes sixteen basic academic disciplines for law students. In 2002, the Chinese authorities combined previous entrance examinations for lawyers, courts and the prosecutor's office into a unified national test. ${ }^{93}$

In Russia, universities have to obtain an education services license. Licensing is performed by the Federal Service for Supervision in Education and Science (Rosobrnadzor), which also provides state accreditation for higher education institutions. Rosobrnadzor is a special body of the Ministry of Education and Science of Russia. The basic functions of the federal authorities in Russia include working out a unified state policy; designing a system of higher education; development, approval and organization of curricula; authorizing public education institutions; approving federal state education standards, licensing and accreditation of education services; and monitoring the education process. ${ }^{94}$

89 The Brazilian Legal Profession, supra note 21, at 30.

90 Ministry of Education of the People's Republic of China (Sep. 10, 2018), available at http://en.moe.gov.cn/.

91 Ministry of Justice of the People's Republic of China (Sep. 10,2018), available at http://en.people.cn/90785/ 7934051.html.

92 Federal Ministry of Education and Science of the Russian Federation (Sep. 10, 2018), available at http:// government.ru/en/department/33/events/.

93 Gerard J. Clark, An Introduction to the Legal Profession in China in the Year 2008, 41(4) Suffolk University Law Review 833 (2008).

94 Federal Ministry of Education and Science, supra note 92. 
Professional associations of lawyers exist both in Russia and in China. In China, these include the All China Lawyers Association (ACLA), the China Law Society (CLS) and the Legal Alliance, which was created in 2010 with the purpose of cooperating with law schools. ACLA was founded in 1986, and its functions are analogous to the $\mathrm{BCl}$ in India and the Bar Association in Brazil. CLS has united the academic community since 1982. ${ }^{95}$ All the Chinese lawyers organizations operate on a voluntary basis and have very limited opportunities to influence government education policy and education quality in China's law schools. They are restricted by government authorities.

Since 2005, the Association of Russian Lawyers (ARL) has united professional lawyers communities across the country; this structure is very similar to the All China Lawyers Association. The difference is that the ARL has authorization to administer accreditations to law schools and faculties. The Presidential Decree "Measures to Improve Higher Legal Education in Russia" of 26 May 2009 grants ARL the powers to improve the quality of legal education and to strengthen control over the activities of educational institutions preparing lawyers. ${ }^{96}$ Special bodies are established under the ARL umbrella: for example, the Commission for the Public Assessment of Legal Education Quality, the Expertise Center for Quality and Law Qualifications Assessment, and the Commission for Legal Research. While state accreditation is based on formal criteria, public accreditation involves informal assessments and is performed by practitioners who understand the problems of higher education and are able to assess the relevance of graduates. From 2011 to 2017 the Association provided certification for 170 out of 1,200 universities with law departments. ${ }^{97}$ Since 2017 , the public accreditation procedure has changed, to the extent that now accreditation is provided to educational programs (undergraduate, graduate, special). On 24 April 2018, 110 law programs from fourteen Russian universities were accredited. ${ }^{98}$ Public accreditation is voluntary, but it has a significant impact on the result of state accreditation.

Another public organization operating in Russia - the Association of Law Universities - is rather academic. It was founded in 1996 and unites 196 law universities. The

95 China Law Society, Academic Dictionaries and Encyclopedias (Sep. 10, 2018), available at http:// en.academic.ru/dic.nsf/enwiki/2697795.

96 Указ Президента Российской Федерации от 26 мая 2009 г. № 599 «О мерах по совершенствованию высшего юридического образования в Российской Федерации», Собрание законодательства РФ, 2009, № 22, ст. 2698 [Presidential Decree No. 599 of 26 May 2009. On Measures to Improve Higher Legal Education in Russia, Legislation Bulletin of the Russian Federation, 2009, No. 22, Art. 2698].

97 Качество юридического образования // Ассоциация юристов России [Association of Russian Lawyers, Quality of Legal Education] (Sep. 10, 2018), available at http://alrf.ru/directions/quality-oflegal-education/.

98 Заседание Комиссии АЮР по общественной оценке качества высшего юридического образования // Ассоциация юристов России. Новости. 24 апреля 2018 г. [Meeting of the ALR Commission on Public Quality Assessment of Higher Legal Education, Association of Russian Lawyers, News, 24 April 2018] (Sep. 10, 2018), available at http://alrf.ru/news/zasedanie-komissii-ayur-po-obshchestvennoyotsenke-kachestva-vysshego-yuridicheskogo-obrazovaniya/. 
members of the association are public and private law schools in Russia, the CIS and other foreign countries that have a license for providing education services. Its main goal is to coordinate the educational and research activities of these law schools. ${ }^{99}$

The quality of legal education in China and Russia, as well as the control over the education process, depends entirely on national education policy. In Russia, there are several target programs approved by the Federal Ministry of Education and Science exemplifying the development of legal education. ${ }^{100}$ The requirements for legal education were sufficiently detailed in four Federal "education standards" (in $1996,2000,2010,2016$ ) which were approved by the relevant orders of the Ministry of Education and Science. A striking trend was the universities' autonomy expansion: for example, universities would be able to independently determine content and the implementation process of academic disciplines. Employers' requirements have been considered in the so-called "competence approach" which lets law schools include many practical activities and training courses within the curricula. The education standard of 2016 strongly recommended that Russian universities teach not "general" legal professional skills, but certain skills for different types of professions (lawyer, judge, corporate lawyer). ${ }^{101}$

The abovementioned normative documents are mandatory for all educational institutions in Russia. Failure to comply with the requirements entails administrative and financial sanctions: reduction of funding and a change in the leadership of the university. Thus, in one of the leading law schools, the Ural State Law University (Yekaterinburg, Russia), the rector's election was postponed for one year (from 2017 to 2018) in order to comply with the directives of the Ministry of Education and Science.

International quality standards have become a reference point for Russia and China with their entry into the Bologna Process in the early 2000s. The Presidential Decree "Measures to Implement the State Policy in Education and Science" of 7 May 2012 set an ambitious goal for at least five Russian universities to enter onto the first 100 list of world university rankings by $2020 . .^{102}$ To implement this goal, the Federal

99 Ассоциация юридических вузов [Association of Law Universities] (Sep. 10, 2018), available at http:// www.jurvuz.ru/ob_assotsiatsii.html.

100 Межведомственная программа «Развитие юридического образования в Российской Федерации на 2001-2005 годы» [Interdepartmental Program "Development of Legal Education in Russia for 2001-2005"] (Sep. 10, 2018), available at http://pravo.gov.ru; Межведомственная программа «Развитие юридического образования в Российской Федерации на 2006-2010 годы» // Юридическое образование и наука. 2007. № 2. С. 3-9 [Interdepartmental Program "Development of Legal Education in Russia for 2006-2010," 2 Legal Education and Science 3, 3-9 (2007)].

101 Приказ Министерства образования и науки Российской Федерации от 1 декабря 2016 г. № 1511 [Order of the Ministry of Education and Science of the Russian Federation No. 1511 of 1 December 2016] (Sep. 10, 2018), available at http://pravo.gov.ru.

102 Указ Президента Российской Федерации от 7 мая 2012 г. № 599 «О мерах по реализации государственной политики в области образования и науки», Собрание законодательства РФ, 2012, № 19, ст. 2336 [Presidential Decree No. 599 of 7 May 2012. On Measures to Implement the State Policy in Education and Science, Legislation Bulletin of the Russian Federation, 2012, No. 19, Art. 2336]. 
Academic Excellence Program "5-100" was started. In 2015, twenty-one universities were involved in this program. ${ }^{103}$ China started the same project earlier and in 2018 five Chinese universities entered onto the first 100 list QS World University Rankings, while the best university in Russia (Moscow State University) occupies the $250^{\text {th }}$ position in these rankings. ${ }^{104}$ In fact, this can be seen as "forced copying" of the American-British university model. That model has become a quality standard because it is supported by international rating agencies. ${ }^{105}$ The governments of China and Russia are adjusting public universities to research universities that are deemed "world class."

At present, some of the rankings used for universities are rather defective in terms of providing an independent evaluation of the effectiveness and quality of higher education. In Russia, apart from the three most authoritative world rankings, other rankings are considered, such as: the Round University Ranking, the National University Ranking (NRA), the rating of the RAEX Agency and the Moscow International University Ranking.

The year 2012 marked a new milestone in the education policy of the Russian Federation. Approximately at the same time, China initiated a new educational model. In 2011, the Central Committee on Politics and Law of the Communist Party of China and the Chinese Ministry of Education published a joint document that defined a new direction for education policy. ${ }^{106}$ Its bottom line is the creation of a new mechanism for evaluating legal educational institutions. Unlike the "211" and "985" programs, which were focused on reforming the universities as a whole, changes are targeted towards legal programs only. The "Outstanding Legal Talent Training Program" launched in 2011 is comprised of several fundamental, new provisions:

1. The program should be implemented not only under the guidance of university administration, but also with the participation of CPC representatives.

2. Chinese legal programs were revised with much political content added. Legal schools are obliged to arrange their curricula with a strong basis of the "socialist rule of law" ideology, which is specific to Chinese society.

3. The curricula are designed so as to teach skills and competencies demanded for certain types of legal professions (judges for rural areas, lawyers in the global economy, government officials and judges in big cities).

At the same time, the process of dividing law schools into two categories "elite" and "mass" - is becoming obvious. There was also a significant reduction in

103 Программа повышения конкурентоспособности 5-100 [5-100 Program for Enhancing Competitiveness] (Sep. 10, 2018), available at http://5100.ifmo.ru/ru/page/35/o_programme.htm.

104 QSWorld University Rankings (Sep. 10, 2018), available at https://www.topuniversities.com/universityrankings/world-university-rankings/2018.

105 Martin Carnoy et al., University Expansion in a Changing Global Economy: Triumph of the BRICS? (Redwood City: Stanford University Press, 2013).

106 Minzner 2013, at 371-376. 
the number of law schools. In Russia, the same process was supplemented by the market ${ }_{107}^{107}$ more so than by administrative ${ }^{108}$ tools.

\section{Conclusions on the Quality of Legal Education}

The quality of education is a common problem of law schools both in developing countries and in countries considered "leaders" of legal education. The reason for this phenomenon lies in the current challenges and dynamic development of economic, cultural, educational processes in the context of globalization. The success of leading countries (i.e. the USA and Great Britain) in pursuit of the high quality of legal education has shown a rapid and adequate response to these challenges. At the same time, it is necessary to create flexible mechanisms not only for regulating the quality of education but also for preserving academic freedom, the most important component of university education.

A common feature of legal education in BRICS is its growing popularity, leading to a number of negative consequences, for example, an excess of lawyers in the labor market; a lack of qualified teaching staff; a drop in the quality of education services and the growth in the number of graduates who are not ready for professional work. Making efforts to solve these problems, India, Brazil, China and Russia have learned from countries across the world regarding the regulation of legal education quality. As a first step towards ensuring a connection with practice, the universities introduced practice-oriented courses, student legal clinics and practicing lawyers to teach special disciplines.

All countries introduced formal procedures for rating and accrediting educational institutions (public-governmental in India, governmental-public in Brazil and governmental in Russia and China). The accreditation certificate is a prerequisite for conducting educational activities and issuing a diploma for a professional lawyer. The ratings of the universities (international and domestic) evaluate many parameters, but primarily scientific work, the demand for graduates and quality standards. The diploma or certificate of higher legal education is a guarantee of receiving government support as well as a position itself on a national and international level. China is the leader among the BRICS countries in terms of the number of educational institutions in prestigious international rankings. Thus, it could be said, that in order to be ranked successfully a law school should follow the American educational pattern.

An effective tool for the regulation of education quality in India, Brazil, China and Russia is the differentiation of law schools into "elite" and "mass" categories. An international research team led by legal scientists from Stanford University studying

\footnotetext{
107 Demand in the labor market, preferences of employers, the popularity of universities, etc.

108 New tools for assessing the qualitative indicators of universities, public funding, the state distribution of student budget places for universities, the system of appointing rectors, etc.
} 
the trends of modern higher education in the BRICS countries concluded that this differentiation of universities and colleges is "the most important change in higher education in the BRIC countries." ${ }^{109}$ However, this new trend is the result of state policy in these four BRICS countries, aimed at strengthening research and training elite staff in a limited number of educational institutions, while the broad demand for higher education is deliberately met with much lower costs. ${ }^{110}$

These conclusions demonstrate the position of legal education in BRICS. China and Russia, having a high centralization in the financing and management of universities, use administrative tools to improve the institutions of legal education; for example, both countries have singled out a group of universities for state support based on achieving excellent academic results. The purpose of these projects is to enter the universities on the world rankings. China and Russia have been aggressively pursuing a policy of building "world class universities," while Brazil and India have been less aggressive."11

The quality of education in the context of different university groups obviously varies: "elite" universities have a higher level of education service quality that are comparable to the standards of the leading world universities. At the same time, the vast majority of law schools in the BRICS countries remain at a rather low level in terms of the quality of education offered. Public authorities and professional law organizations in India, Brazil, China and Russia are taking administrative and marketbased measures to reduce inefficient educational institutions, whose numbers are still very large. The results of a sociological survey in Russia showed two trends in legal education - firstly, there is a demand for cheaper education services, regardless of their quality. Secondly, there is the issue of a society split into rich and poor where big law schools provide better access to higher education, which is, to some extent, an element of social justice. ${ }^{112}$

The difference in ensuring the quality of legal education within BRICS is the tools used for the standardization of the education process. In India, standards are predominantly formed by public authorities (the Bar Council of India and the University Grants Commission) jointly with federal and regional bodies (the National Council for Assessment and Accreditation (NAAC), the National Knowledge Commission). In Brazil, the main actors in this process are state authorities (the Ministry of Education, the National Council for Education) with the active participation of representatives of the legal community (OAB). In China and Russia, public authorities (bodies of executive power) are in charge of education standards alongside the public accreditation of Russian universities by the Association of Russian Lawyers.

\footnotetext{
109 Martin Carnoy et al. 2013, at 7.

$110 \quad$ Id. at 75 .

111 Id. at 245.

112 Legal Education, supra note 40, at 15-34.
} 
Russia and China have more centralized and stricter requirements for the curricula. The governments of India and Brazil establish only minimal requirements, allowing the law schools to independently determine the list, scope and process of teaching for all academic disciplines. However, Russian law schools are becoming more independent since the new education standard was adopted in 2017.

The quality control in BRICS law schools is also implemented in very different ways. In India, law school graduates take the All India Bar Exam every year. In Brazil, an analogous exam - the National Exam for the Assessment of Student Performance is mandatory. The difference is that students take it twice: in the first year and in the last. This measures the quality of the graduates' knowledge. In China, since 2002, there has been a unified National Exam (test) for those wishing to work in the legal field. In Russia, graduates of law schools take state exams, the content of which is determined by the institution itself. For those wishing to start a career in a law firm or in the judiciary there are special qualification exams to do so.

\section{Conclusion - Tendencies and Challenges of Legal Education in BRICS}

The BRICS countries began to dramatically expand their higher education systems in the $20^{\text {th }}$ century when the effects of globalization were seen to be reaching deep into economics, politics and other areas. The demands for lawyers' competencies and changing markets brought new interest in higher education and the need for reforms. Most countries took the American educational system as a useful benchmark for such reforms, striving to create leading research universities. At the same time, changes in legal education were an important part of the efforts made by the countries' leadership to adapt their political, legal, economic and social institutions in accordance with the rapidly changing global community.

In these new conditions, Russia, among the four BRICS countries under study in this paper, is in the least favorable situation. Losing its economic and political leadership roles and with weak democratic traditions, the country has failed to reform legal education successfully in comparison to the other three BRICS countries and in line with legal education trends worldwide. However, despite the unfavorable circumstances, significant positive changes are visible in legal education in Russia over the past ten to fifteen years. These changes reflect the global policy of creating worldclass universities and international standards in reforming the education system.

The comparison of the education reforms in the four BRICS countries shows that China has made the most progress in terms of self-identification and supporting national priorities. The country's policy of "socialist rule of law" has been much criticized; however, through its means the "Outstanding Legal Talent Training Program" was successfully implemented. This was due to the growing conflict between Western liberal legal values, which were widely broadcast at legal universities throughout the 
country, on the one hand, and traditional Chinese values and public interests, on the other. The process of education reform was supported by the country's rapidly developing economy, which is the largest economy in the world, and has a growing influence on global educational trends.

Legal education in Brazil is associated with a high degree of adaptation of the country's legal practice to international cooperation, with the leading role of large legal corporations. This circumstance has caused wide distribution of programs of continuous legal education, in-house legal training and the development of "mass" legal schools. A significant particularity is that in-house legal education is not regulated by the Brazilian government as compared to other educational institutions in BRICS.

Legal education in India is characterized by a multilevel and complex structure related to previous British influence. India's specific feature is the distribution of responsibility for the quality of legal education between public professional organizations (the Bar Council of India, the University Grants Commission), the public authorities (the National Commission for Legal Knowledge) and, to a lesser extent, the participation of federal and local governmental bodies. Thus, in China and Russia state regulation of higher legal education prevails, while in Brazil and India market mechanisms are more widely used.

Legal education in BRICS has shared the same trends in terms of internationalization and increasing popularity, thus bringing about the explosion of mass law schools and the introduction of reforms to bring about progressive changes in their higher education systems.

Therefore, the question of how law schools can best prepare their graduates to practice law in this new "world without borders" is a crucial matter. ${ }^{113}$ Despite the existence of certain potential obstacles, cooperation in the sphere of legal education between the BRICS countries has a high development potential. ${ }^{114}$ The internationalization of legal education, teaching of comparative law and lawyer awareness of issues important for the BRICS countries' development are appropriate responses to the challenges of legal practice in the $21^{\text {st }}$ century. The globalization of legal education is certain to continue. Nevertheless, national drivers will continue to influence the development of legal education in BRICS, and two factors can change the pace of it. The first is the marketplace. If employers conclude that lawyers educated with a global perspective bring added value to transactions or litigation, there will be demand for law schools offering such training. Students are the second: if they conclude that a global perspective of law enhances their career opportunities

113 Muna Ndulo, Legal Education in an Era of Globalization and the Challenge of Development, Cornell Law Faculty Publications, Paper 987 (2014) (Sep. 10, 2018), available at http://scholarship.law.cornell. edu/facpub/987.

114 Dmitry Maleshin, Chief Editor's Note on Legal Education in BRICS Countries, 2(1) BRICS Law Journal 4, 6 (2015). 
and mobility, they will devalue a law school without such a perspective. Having this in mind, stakeholders in education should strive to ensure that legal education reflects all the needs of the country and, moreover, contributes to the economic and governance development of the BRICS group.

\section{References}

Berman H.J. The Crisis of Legal Education in America, XXVI(2) Boston College Law Review 347 (1985).

Clark G.J. An Introduction to the Legal Profession in China in the Year 2008, 41(4) Suffolk University Law Review 833 (2008).

Dasgupta L. Reforming Indian Legal Education: Linking Research and Teaching, 59(3) Journal of Legal Education 432 (2010).

Folsom R.H. et al. International Business Transactions: A Problem-Oriented Coursebook ( $11^{\text {th }}$ ed., St. Paul, MN: West, 2012).

Gelatt T. \& Snyder F. Legal Education in China: Training for a New Era, 1 China Law Report 41 (1980).

Jacobs B. \& van der Ploeg F. Guide to Reform of Higher Education: A European Perspective, 21(47) Economic Policy 535 (2006).

Kashyap A.K. Professional Legal Education in India: Challenges and the Way Forward, 7(3) Educational Quest: An International Journal of Education and Applied Social Sciences 141 (2016).

Kinoy A. The Present Crisis in American Legal Education, 24 Rutgers University Law Review 1 (1969).

Legal Education in India: Challenges and Perspectives (G.M. Rao \& K.S. Rao (eds.), Hyperabad: Asia Law House, 2010).

Legal Education in India: Issues and Challenges (K.L. Gupta (ed.), Germany: Lambert Academic Publication, 2017).

Legal Education in India: Problems and Perspectives (S.K. Agrawala (ed.), Bombay: N.M. Tripathi, 1973).

Lucas R.E., Jr. On the Mechanics of Economic Development, 22(1) Journal of Monetary Economics 3 (1988).

Maleshin D. Chief Editor's Note on Legal Education in BRICS Countries, 2(1) BRICS Law Journal 4 (2015).

Maleshin D. The Crisis of Russian Legal Education in Comparative Prospect, 66(2) Journal of Legal Education 289 (2017).

Mankiw N.G. et al. A Contribution to the Empirics of Economic Growth, 107(2) Quarterly Journal of Economics 407 (1992).

Minzner C.F. The Rise and Fall of Chinese Legal Education, 36(2) Fordham International Law Journal 335 (2013).

Parmar R. Problems and Challenges of Legal Education, 5(9) International Journal of Management and Social Sciences Research 53 (2016). 
Pedrosa R.H.L. et al. Assessing Higher Education Learning Outcomes in Brazil, 24(2) Higher Education Management and Policy 55 (2013).

Phan P.N. Clinical Legal Education in China: In Pursuit of a Culture of Law and a Mission of Social Justice, 8(1) Yale Human Rights and Development Journal 117 (2005).

Radulescua I.G. et al. BRICS Countries Challenge to the World Economy New Trends, 8 Procedia Economics and Finance 605 (2014).

Reimann M.W. et al. Transnational Law: Cases and Materials (St. Paul, MN: West, 2013).

Romer P. Endogenous Technological Change, 98(5) Journal of Political Economy S71 (1990).

Sarker S.P. Empowering the Underprivileged: The Social Justice Mission for Clinical Legal Education in India, 19 International Journal of Clinical Legal Education 321 (2015).

Sautman B. Politicization, Hyperpoliticization and Depoliticization of Chinese Education, 35(4) Comparative Education Review 669 (1991).

Sheng-jun Y. Educational Policies and Economic Growth in BRICS: Comparative Perspectives, 8(2) Journal of US-China Public Administration 188 (2011).

Wan Y. Expansion of Chinese Higher Education Since 1998: Its Causes and Outcomes, 7(1) Asia Pacific Education Review 19 (2006).

\section{Information about the authors}

Oleg Vinnichenko (Tyumen, Russia) - Professor, Theory of Law and International Law Department, Tyumen State University (38 Lenina St., Tyumen, 625000, Russia; e-mail: ole.vinnichenko@yandex.ru).

Elena Gladun (Tyumen, Russia) - Associate Professor, Finance and Public Law Department, Tyumen State University (38 Lenina St., Tyumen, 625000, Russia; e-mail: efgladun@yandex.ru). 